\title{
PENINGKATKAN KARAKTER \\ DENGAN METODE COOPERATIFLEARNING PADA PEMBELAJARAN MICROTEACHING MAHASISWA JURUSAN PENDIDIKAN BAHASA PRANCIS FBS UNY
}

\author{
Siti Sumiyati, Alice Armini, dan Roswita Lumban Tobing \\ Fakultas Bahasa dan Seni, Universitas Negeri Yogyakarta \\ yatimsaleh05@gmail.com
}

\begin{abstract}
ABSTRAK
Penelitianini bertujuan untuk meningkatkan karakter mahasiswa mahasiswa Jurusan Pendidikan Bahasa Prancis melalui pembelajaran Microteaching. Peningkatan karakter difokuskan pada dua aspek yaitu rasa tanggung jawab dan kerjasama. Penelitian ini merupakan penelitian tidakan kelas yang dilaksanakan dalam dua siklus dari tanggal 5 Mei 2014 sampai dengan 23 Mei 2014. Pengumpulan data dilakukan melalui observasi, catatan lapangan, dan dokumentasi. Hasil penelitian menunjukkan bahwa proses pembelajaran microteaching dengan penerapan metode cooperative learning dapat meningkatkan karakter mahasiswa. Peningkatan nilai rasa tanggung jawab dari pratindakan ke Siklus I dan Siklus II berturut-turut 4,2\% dan 18,7\%; sedangkan peningkatan nilai kerjasama pada Siklus I dan II adalah $44 \%$ dan 58,6\%. Mahasiswa yang mencapai target keberhasilan penelitian sebesar $96 \%$. Dengan demikian, penerapan metode cooperative learning dapat meningkatkan nilai karakter mahasiswa semester VI Jurusan Pendidikan Bahasa Prancis yang sedang menempuh mata kuliah Microteaching,
\end{abstract}

Kata kunci: karakter, metode cooperative learning, tanggung jawab, kerjasama.

\section{IMPROVING CHARACTER THROUGH COOPERATIVE LEARNING METHOD IN MICROTEACHING CLASS OF FRENCH EDUCATION DEPARTEMENT STUDENTS OF FACULTY OF LANGUAGES AND ARTS OF YOGYAKARTA STATE UNIVERSITY}

\begin{abstract}
This research aims to improve students' character in microteaching class through cooperative learning. This reseach is classroom action research which is focused on two character's aspect, ie: (1) responsibility and (2) cooperation.

The subject of this research is French departement students at $6^{\text {th }}$ semestre, who are sitting on microteahing class. They are 5 men and 18 women. This research was conducted in two cycles, from $5^{\text {th }}$ to $23^{\text {th }}$ May 2014. Data collection was obtained through the obsevations and documents analysis. The research was donein collaborationwithteachers of French departement.

The results of this research showed thatthroughcooperative learning, thecharacter in responsibility and cooperation aspect of the students in microteahing classis increasing. It is evident from the development of responsibility: 4,2 \% in cycle I and 18,7\% in cycle II; and the development of cooperation: $44 \%$ in cycle I and 58,6\% in cycle II.
\end{abstract}

Keywords: character, cooperative learning method, responsibility, cooperation

\section{PENDAHULUAN}

Pembentukan karakter merupakan salah satu tujuan pendidikan nasional. Pasal I UU Sisdiknas Tahun 2003 menyatakan bahwa di antara tujuan pendidikan nasional adalahmengembangkan potensi peserta didik untukmemiliki kecerdasan, kepribadian dan akhlak mulia. UU Sisdiknas Tahun 2003 itu bertujuan agar pen- 
didikan tidak hanya membentuk insan Indonesia yang cerdas, namun juga berkepribadian atau berkarakter, dengan harapan agar nantinya akan lahir generasi bangsa yang tumbuh dan berkembang dengan karakter yang bernafas nilai-nilai luhur bangsa dan agama. Pendidikan yang mengimplementasikan nilai-nilai karakter adalah salah satu upaya membentuk manusia secara utuh yang berkarakter, yaitu mengembangkan aspek fisik, emosi, sosial, kreativitas, spiritual, dan intelektual secara optimal.

Pendidikan karakter tidak semata-mata bersifat individual, tetapi juga memiliki dimensi sosial struktural. Meskipun pada gilirannya kriteria penentu adalah nilai-nilai kebebasan individual yang bersifat personal. Pendidikan karakter yang berkaitan dengan dimensi sosial struktural, lebih melihat bagaimana menciptakan sebuah sistem sosial yang kondusif bagi pertumbuhan individu. Dalam konteks inilah, kita dapat meletakkan pendidikan moral dalam kerangka pendidikan karakter. Pendidikan moral itu sendiri merupakan pondasi bagi sebuah pendidikan karakter. Hal ini juga merupakan bagian dari tugas UNY seperti yang terdapat pada Peraturan Rektor No. 4 Tahun 2009 tentang Pengembangan Kultur UNY dan juga nilai-nilai yang sudah disepakati untuk: (1) ditargetkan seperti yang sudah dijabarkan dalam buku: Pendidikan Karakter: Grand Design dan Nilai-Nilai Target (UNY Press, 2009); (2) mengembangkan komitmen untuk mengejawantahkan nilai-nilai tersebut; dan (3) membiasakan berperilaku selaras dengan nilai-nilai tersebut.

Sehubungan dengan pemahaman tersebut, upaya untuk meningkatkan kualitas diri dan kepribadian mahasiswa dalam bentuk karakter melalui proses pembelajaran merupakan kebutuhan yang mendesak untuk dilakukan. Sebagai calon guru, mahasiswa Jurusan Pendidikan Bahasa Prancis FBS UNY harus memiliki karakter calon sosok guru, dan dituntut untuk menjadi contoh teladan baik bagi peserta didik maupun orang lain. Pembetukkan sikap, kepribadian moral dan sosok calon guru dimulai dari semester satu. Namun demikian, karakter calon sosok guru masih perlu dikembangkan sehingga menjadi sikap, kepribadian sosok calon guru sebagaimana yang harapkan. Salah satu upaya yang dilakukan oleh tim peneliti Jurusan pendidikan
Bahasa Perancis untuk membantu meningkatkan karakter yaitu dengan menggunakan metode cooperative learning pada mahasiswa Jurusan Pendidikan Bahasa Prancis FBS UNY.

Terkait dengan pendidikan karakter ini, Lickona (1999: 53) menyatakan bahwa pengembangan karakter dapat dilaksanakan melalui tahap pengetahuan (knowing), acting, menuju kebiasaan (habit). Hal ini berarti karakter tidak sebatas pada pengetahuan, dan karakter seseorang yang dapat berubah dengan upaya-upaya tertentu, salah satunya dengan penggunaan metode cooperative learning. Metode cooperative learning adalah model pembelajaran yang dilandasi oleh pendapat Vygotsky bahwa peningkatan fungsi-fungsi mental seseorang berasal dari kehidupan sosial atau kelompoknya dan bukan sekedar dari individu itu sendiri (Budiningsih, 2005:100). Hal ini senada dengan pendapat (Kuntoro dalam FIP UNY, 2013:5051) bahwa kegiatan belajar merupakan bagian dari kegiatan kehidupan. Oleh karena itu, aktivitas belajarpun terjadi dalam konteks sosial. Dengan demikian, belajar selalu belajar sosial, yakni belajar dari orang lain dan belajar bersama orang lain.Kontribusi metode cooperative learning dalam proses pembelajaran ini dilandasi konsep zona perkembangan proksimal (zone of proximal development) yang menyatakan bahwa ketika berkolaborasi dengan teman sebaya yang lebih kompeten seseorang dapat melakukan dan menemukan lebih banyak hal dibanding dengan seseorang belajar sendiri (Budiningsih, 2005: 101). Adapun berdasarkan teori Vygotsky tersebut, keuntungan yang dapat diperoleh, yaitu: (1) mahasiswa memperoleh kesempatan untuk mengembangkan zona perkembangan proksimalnya, (2) pembelajaran senantiasa lebih dikaitkan pada tingkat perkembangan potensial dari pada tingkat perkembangan aktualnya, (3) pembelajaran lebih diarahkan pada penggunaan strategi untuk mengembangkan kemampuan intermentalnya dari pada kemampuan intramentalnya, dan (4) proses belajar dan pembelajaran tidak sekedar bersifat transferal namun lebih memanifestasikan kokonstruksi, yakni suatu proses mengonstruksi dalam hal ini perilaku berkarakter secara bersama-sama antara semua pihak yang terlibat dalam proses pembelajaran(Budiningsih, 2005: 104). 
Ruang lingkup kompetensi guru meliputi kompetensi kepribadian, kompetensi pedagogik, kompetensi professional dan kompetensi sosial. Ahlak mulia merupakan subkompetensi kepribadian. Mengingat terbatasnya waktu dan tenaga, maka karakter yang diteliti difokuskan pada dua aspek aklak mulia yaitu tanggung jawab dan kerjasama. Kedua aspek ini diamati pada saat mahasiswa praktik mengajar. Diharapkan dengan pengintegrasian karakter para mahasiswa memiliki etos kerja sama yang memadai dan dapat meningkatkan tanggung jawab serta budi pekerti dalam kehidupan kampus secara menyeluruh, sehingga tercipta generasi yang bermoral dan bertanggungjawab serta mampu menunjukkan jati dirinya sebagai manusia yang berbudaya dan dapat meningkatkan kualitas kepribadian sosok calon guru.

Penelitian ini bertujuan untuk meningkatkan karakter mahasiswa semester VI Jurusan Pendidikan Bahasa Prancis FBS UNY. Definisi konseptual yang digunakan dalam penelitian ini karakter adalah nilai-nilai yang unik-baik (tahu nilai kebaikan, mau berbuat baik, dan nyata berkehidupan baik) yang terpatri dalam diri dan terejawantahkan dalam perilaku. Adapun definisi operasional dalam penelitian ini dibatasi pada pengintegrasian karakter kerja sama dan tanggung jawab.

Tanggung jawab merupakan sikap dan perilaku seseorang untuk melaksanakan tugas dan kewajiban, yang seharusnya dilakukan terhadap diri sendiri, masyarakat, lingkungan, negara dan Tuhan Yang Maha Esa. Dalam penelitian ini tanggung jawab yang dimaksud adalah tanggung jawab sebagai mahasiswa calon guru, warga kelas dan warga universitas dan calon warga tenaga kependidikan di suatu sekolah. Indikator tanggung jawab adalah melakukan tugas sesuai jadwal yang tealah ditentukan dalam kegiatan microteaching, memberi materi yang sesuai dengan yang dicantumkan dalam RPP, memberikan penjelasan materi ajar yang diyakini benar, memberikan informasi yang relevan dengan topik yang sedang dibahas, menunjukkan sikap percaya diri dalam melakukan tugas, berkomunikasi dan berinteraksi secara efektif dan santun, menjelaskan materi ajar secara sistematis dan logis, menerapkan metode pembelajaran secara kritis, kreatif, dan inovatif, menerapkan media pembelajaran yang sesuai dengan materi ajar secara kreatif, menerapkan metode yang dipilih secara inovatif, menunjukkan sikap kompetitif untuk mendapatkan hasil yang terbaik, menunjukkan sikap sportif untuk mendapatkan hasil yang terbaik, tampil maksimal dalam pembelajaran mikro secara individual, menggunakan media secara kreatif baik secara individual untuk membantu siswa dalam penguasaan materi yang diajarkan, mengatakan sesuatu yang diyakini benar, menghindari pertanyaan-pertanyaan yang tidak benar, menyampaikan pertanyaan-pertanyaan yang tidak samar, komunikasi dengan siswa dalam upaya menghidupkan kelas, menunjukkan kemampuan belajar secara mandiri sesuai dengan potensi yang dimiliki, menunjukkan keterampilan menyimak, berbicara dalam bahasa prancis yang dimiliki, menerapkan kesesuaian tujuan pembelajaran secara mandiri sesuai dengan potensi yang dimiliki, menunjukkan keterampilan menyimak, berbicara dan menulis dalam bahasa prancis, menerapkan strategie métacognitve untuk membantu belajar siswa, berkomunikasi dan berinteraksi secara efektif dan santun, menggunakan media secara kreatif baik secara individual untuk membantu siswa dalampenguasaan materi yang diajarkan, melakukan tugas sesuai jadwal yang tealah ditentukan dalam kegiatan microteaching, melaksanakan phases cognitive, associative et phase de l'automatisation untuk memfasilitasi proses construction du savoir, mengecek pemahaman/memperjelas pertanyaan, menunjukkan upaya terciptanya kelompok, dan menunjukkan kemampuan membangkitkan motivasi siswa untuk berbicara.

Kerjasama adalah sikap dan perilaku seseorang yang mencerminkan adanya kesadaran dan kemauan untuk bersama-sama saling membantu, dan saling memberi tanpa pamrih. Kerjasama merupakan kegiatan yang dilakukan oleh beberapa orang untuk mencapai tujuan bersama. Indikator tanggung jawab dibatasi pada hal berikut: berpartisipasi aktif dalam kegiatan microteaching, mendukung aktivitas teman dalam praktek menngajar dalam microteaching, menyatakan pendapat yang positif terhadap aktivitas yang dilakukan teman, membicarakan anggota lain dalam kelompok secara positif, 
menghargai hasil yang dicapai anggota kelompok microteaching, menghargai masukan dari orang lain, meminta ide dan pendapat kepada semua anggota untuk membantu perbaikan pelaksanaan microteaching, mendorong kerjasama kelompok anggota microteaching, memberi pujian orang yang mempunyai pendapat baik, mendorong anggota lain untuk ikut berperan, membuat anggota lain merasa kuat dan penting, menciptakan suasana kelompok yang akrab, menyelesaikan perselisihan yang terjadi dalam kelompok, melindungi reputasi anggota kelompok yang lain, memberi sumbangan informasi sesuai yang dibutuhkan, mengatakan sesuatu yang saya yakin benar, memberikan informasi yang relevan, menyampaikan pernytataan-pernyataan yang tidak samar, menyatakan pernyataanpernyataan yang tidak ambigu, menghormati pendapat orang lain, berbicara dengan teman sebelah ketika kelompok lain sedang presentasi, menahan diri ketika ada perbedaan pendapat antar kelompok, akan berbicara secara bergantian dengan anggota lain, memutus pembicaraan orang lain, memberi kesempatan agar semua peserta dapat mengambil bagian, berbicara terlalu lama, berperan sebagai siswa yang sesungguhnya pada waktu pelaksanaan pengajaran mikro, mengajukan pertanyaan kepada model guru, menjawab pertanyaan guru dan menjawab tidak paham jika perlu, dan melaksanakan tugas sesuai dengan kesepakatan

\section{METODE PENELITIAN}

Penelitian ini merupakan Penelitian Tindakan Kelas (Classroom Action Research) karena penelitian ini menggunakan langkahlangkah PTK. Penelitian yang ditempuh mulai dari tahap perencanaan, pelaksanaa, observasi dan refleksi yang bertujuan untuk meningkatkan karakter dengan metode cooperative learning mahasiswa pada pembelajaran microteaching bagi mahasiswa VI Jurusan Pendidikan Bahasa Prancis FBS UNY. Penelitian Tindakan Kelas dilakukan di laksanakan di FBS UNY mulai dari tanggal 5 Mei sampai dengan 23 Mei 2014. Subjek penelitian ini adalah mahasiswa Jurusan Studi Pendidikan Bahasa Prancis, FBS UNY semester VI, yang mengikuti matakuliah $\mathrm{Mi}$ croteaching, terdiri dari 23 mahasiswa, 5 orang lelaki dan 18 perempuan. Teknik pengumpulan data yang digunakan dalam penelitian ini, yaitu teknik nontes yang menggunakan observasi, catatan lapangan dan dokumentasi.Target pencapaian keberhasilan penelitian ini yaitu apabila $80 \%$ dari 23 mahasiswa telah berhasil mencapai nilai berkategori baik, yakni memperoleh skor terendah 76 dari skor maksimum 120.

Setelah menggumpulkan data dari hasil observasi proses pembelajaran microteaching di kelas, catatan harian, data dianalisis secara deskriptif yaitu mendekripsikan sebagaimana adanya tanpa bermaksud membuat generalisasi. Hasil analisis data tersebut menjadi bahan refleksi untuk langkah penelitian selanjutnya. Data hasil observasi proses pembelajaran dianalisis secara deskriptif yang berguna untuk melihat peningkatan karakter menggunakan metode $\mathrm{co}$ operative learning. Pada saat pengamatan ditulis kejadian-kejadian yang unik selama pelaksanaan perkuliahan. Catatan dosen dan hasil observasi digunakan sebagai data pendukung untuk menentukan keberhasilan pembelajaran.

Prosedur dalam penelitian ini terdiri dari 2 (dua) siklus masing-masing siklus terdiri dari 4 (empat) tahapan, yaitu: (1) perncanaan, (2) pelaksanaan, (3) observasi,(4) refleksi. Masingmasing tahapan pelaksanaan dilakukan dalam 3 (tiga) pertemuan.

\section{HASIL DAN PEMBAHASAN}

Proses pembelajaran microteaching yang dilaksanakan dengan metode cooperative learning cocok dilakukan, karena metode ini menekankan hubungan individu dengan kelompok atau individu dengan orang lain. Interaksi sosial antarindividu yang terjadi dimanifestasikan dalam belajar secara kolaboratif sehingga peluang terjadinya hubungan yang saling mempenaruhi sangat terbuka baik disengaja maupun tidak disengaja.

Metode cooperative learning memberi peluang terjadinya hubungan saling mempengaruhi antarindividu. Metode ini dapat meningkatkan kemampuan individu dalam berhubungan dengan orang lain, dan pada akhirnya mahasiswa dapat menampilkan karakter yang baik yang telah terinternalisasi dalam diri mahasiswa dengan ditunjukkan dalam perilaku sehari-hari sebagai produk dari hasil pembelajaran integrasi nilai. 
Pembelajaran microteaching dengan metode cooperative learning dilaksanakan selama dua siklus. Pada Siklus I, calon guru sudah tidak lagi melakukan kesalahan pelafalan sebagaimana yang terjadi pada kegiatan pratindakan. Calon guru sudah menerapkan metode cooperative learning sehingga anak didik belajar bersama dalam kelompok kecil. Kendala yang ditemui pada siklus pertama yaitu (1) calon guru kurang menguasi materi, (2) menggunakan media pembelajaran kurang optimal, dan (3) melaksanakan aktivitas pembelajaran tidak sesuai dengan RPP. Sementara itu, mahasiswa yang berperan sebagai anak didik selama Siklus I terlihat antusias, responsif dan melibatkan diri dalam aktivitas belajar. Dari hasil observasi diperoleh informasi adanya 7 (tujuh) indikator aspek tanggung jawab yang jarang tampak, yaitu: (1) melaksanakan phases cognitive, associative et phase de l'automatisation, (2) menyampaikan pertanyaan-pertanyaan yang tidak samar, (3) menunjukkan upaya terciptanya kelompok, (4) menunjukkan kemampuan membangkitkan motivasi siswa untuk berbicara, (4) menerapkan metode pembelajaran secara kritis, kreatif, dan inovatif, (5) menerapkan strategie métacognitve untuk membantu belajar siswa, (6) mengecek pemahaman/ memperjelas pertanyaan, dan (7) menunjukkan sikap kompetitif untuk mendapatkan hasil yang terbaik. Sementara itu, empat indikator aspek kerjasama yang jarang tampak, yaitu: (1) menjawab pertanyaan guru dan menjawab tidak paham jika perlu, (2) melaksanakan tugas sesuai dengan kesepakatan, (3) berperan sebagai siswa yang sesungguhnya pada waktu pelaksanaan pengajaran mikro, (4) mendorong kerjasama kelompok anggota microteaching.

Pada Siklus II, Pelaksanaan pembelajaran microteaching berjalan lancar. Pelaksanaan praktik mengajar oleh calon guru memuaskan.
Para calon guru sudah tampil maksimal, materi yang disampaikan jelas, dan mudah dipahami. Media pembelajaran yang digunakan sudah memadai. Meskipun demikian, masih ada 3 dari 12 calon guru terlihat belum lancar dalam kegiatan tanya jawab. Mahasiswa yang berperan sebagai anak didik sudah melaksanakan perannya dengan baik, kerjasama antaranak didik terlaksana dengan baik, anak didik mengajukan pertanyaan, menyatakan pendapat dan argumen, meminta penjelasan.

Kendala yang ditemui pada siklus kedua yaitu ada tiga calon guru kurang lancar dalam aktivitas tanya jawab. Hal ini menunjukkan bahwa performance berbicara dalam bahasa Prancis mahasiswa yang bersangkutan perlu lebih ditingkatkan. Pada aspek tanggung jawab terdapat dua indikator yang masih jarang terlihat, yaitu (1) melaksanakan phases cognitive, associative et phase de l'automatisation untuk memberikan kemudahan pada proses construction du savoir, dan (2) menunjukkan kemampuan membangkitkan motivasi anak didik untuk berbicara.

\section{Karakter yang Dihasilkan}

Setelah diterapkan metode cooperative learning karakter mahasiswa mengalami peningkatan. Bukti peningkatan karakter mahasiswa dalam dua aspek, yaitu tanggung jawab dan kerjasama dapat dilihat pada Tabel 1 .

Pada Tabel 1 tersebut ditunjukkan bahwa pada saat pratindakan perilaku mahasiswa dalam tanggung jawab dan kerjasama sudah termasuk dalam kategori baik. Namun demikian, rerata skor rasa tanggung jawab lebih tinggi daripada rerata skor kerjasama $(82,43>$ $80,17)$. Setelah siklus kedua berakhir, perilaku mahasiswa dalam tanggung jawab tetap menempati posisi lebih tinggi dibandingkan dengan

Tabel 1. Skor Karakter Mahasiswa dalam Dua Siklus

\begin{tabular}{lllccc}
\hline No. & Siklus ke & $\begin{array}{c}\text { Aspek yang } \\
\text { Diobservasi }\end{array}$ & $\begin{array}{c}\text { Skor Rata- } \\
\text { rata Kelas }\end{array}$ & $\begin{array}{c}\text { Mahasiswa Yang Mencapai } \\
\text { Jumlah Target Persentase }\end{array}$ \\
\hline 1. & Pratindakan & Tanggung jawab & 82,43 & 19 & $82,61 \%$ \\
& & Kerjasama & 80,17 & 18 & $78,26 \%$ \\
2. & Siklus I & Tanggung jawab & 85,91 & 20 & $86,96 \%$ \\
& & Kerjasama & 83,82 & 20 & $86,96 \%$ \\
3. & Siklus II & Tanggung jawa & 97,78 & 22 & $95,65 \%$ \\
\hline
\end{tabular}


kerjasama, meskipun skor rata-rata kelas aspek kerjasama juga sudah meningkat dari 80, 17 menjadi 92,26.

\section{Tanggung Jawab}

Perilaku tanggung jawab meliputi 30 indikator sebagaimana telah diuraikan pada pendahuluan. Dari Grafik 1 berikut dapat diketahui peningkatan perilaku mahasiswa untuk tanggung jawab selama dua siklus.

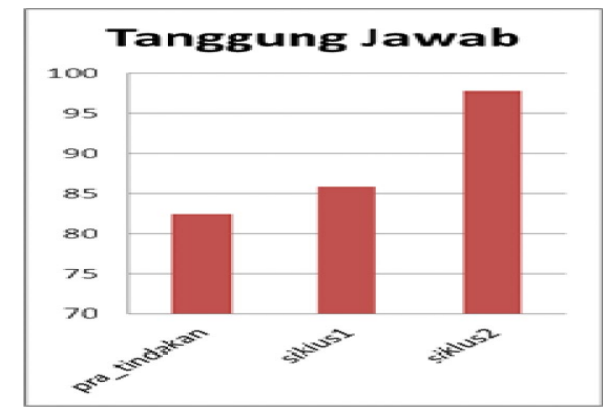

Grafik 1. Peningkatan Karakter Tanggung Jawab

Berdasarkan Grafik 1 tersebut, dapat dilihat bahwa perilaku mahasiswa dalam tanggung jawab mengalami peningkatan dari Siklus I dari pratindakan ke Siklus I dan Siklus II berturut-turut $4,2 \%$ dan $18,7 \%$, sedangkan jumlah mahasiswa yang mencapai target naik $8,69 \%$, yaitu dari 20 orang mahasiwa menjadi 22 orang mahasiswa.

\section{Kerjasama}

Perilaku tanggung jawab meliputi 30 indikator sebagaimana telah diuraikan pada pendahuluan. Dari Grafik 2 berikut dapat diketahui peningkatan perilaku mahasiswa untuk kerjasama selama dua siklus.

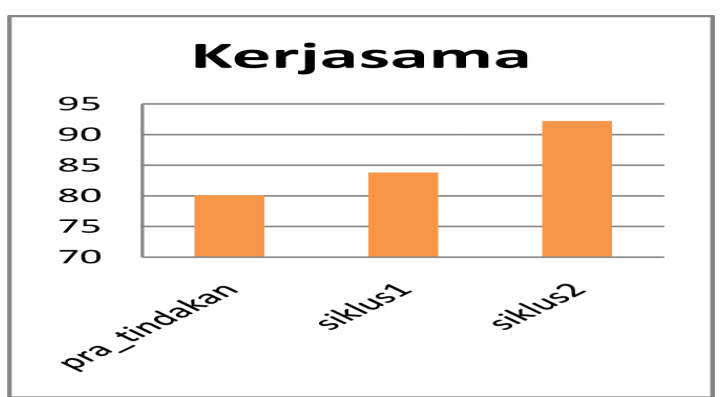

Grafik 2. Peningkatan Karakter Kerjasama
Berdasarkan Grafik 2 tersebut, dapat dilihat bahwa perilaku mahasiswa dalam kerjasama mengalami peningkatan dari pratindakan ke Siklus I dan Siklus II berturut-turut. Peningkatan nilai kerjasama pada Siklus I dan II adalah 44\% dan $58,6 \%$,sedangkan jumlah mahasiswa yang mecapai target naik $8,69 \%$, yaitu dari 20 orang mahasiwa menjadi 22 orang mahasiswa. Dengan demikian, mahasiswa yang mencapai target keberhasilan penelitian sebesar $96 \%$.

\section{PENUTUP}

Berdasarkan deskripsi hasil penelitian dan pembahasan yang telah diuraikan dapat disimpulkan sebagai berikut. Pertama, pelaksanaan pembelajaran microteaching dengan menggunakan metode cooperative learning pada mahasiswa semester VI Jurusan Pendidikan Bahasa Prancis FBS UNY berlangsung dengan lancar. Dari segi produk, terjadi peningkatan nilai karakter mahasiswa dengan meningkatnya skor rata-rata kelas pada aspek rasa tanggung jawab dan kerjasama dari pratindakan sampai dengan siklus kedua. Kedua, peningkatan nilai karakter pada kedua aspek tersebut dapat dilihat melalui skor rata-rata kelas mulai dari kegiatan pratintakan hingga siklus kedua, yakni pada kegiatan pratindakan skor rata-rata kelas untuk aspek tanggung jawab yang diperoleh sebesar 82,43 , sedangkan untuk aspek kerjasama skor rata-rata kelas yang diperoleh sebesar 80,17. Pada siklus pertama skor rata rata kelas untuk aspek tanggung meningkat menjadi 85,91, sedangkan untuk aspek kerjasama skor rata-rata kelas juga meningkat menjadi 83,82. Pada siklus kedua perolehan skor rata-rata kelas untuk aspek rasa tanggung jawab dan kerjasama juga terus meningkat. Skor rata-rata kelas untuk aspek rasa tanggung jawab meningkat menjadi 97,78, sedangkan skor rata-rata kelas kerjasama juga terus meningkat menjadi 92,26. Dengan demikian, disimpulkan bahwa mulai dari kegiatan pratindakan hingga siklus kedua terjadi peningkatan skor rata-rata kelas untuk aspek tanggung jawab sebesar 15,35, sedangkan skor rata-rata kelas untuk aspek kejasama sebesar 12,09.

Berdasarkan kesimpulan yang diperoleh, implikasinya adalah bahwa penggunaanmetode cooperative learning merupakan salah satu cara yang dapat digunakan untuk mening- 
katkan nilai karakter mahasiswa. Internalisasi nilai karakter perlu diprogramkan secara nyata oleh dosen dalam suatu rancangan pelaksanaa pembelajaran.

Beberapa saran yang dapat peneliti berikan berdasarkan hasil penelitian ini adalah: Dosen hendaknya meneruskan internalisasi nilai karakter. Internalisasi nilai karakter perlu dikembangkan secara komprehensif dalam proses perkuliahan untuk dikaitkan dengan nilai karakter yang sedang ditargetkan.

\section{UCAPAN TERIMA KASIH}

Artikel ini disarikan dari hasil penelitian institusional yang dilaksanakan dengan anggaran dana DIPA UNY tahun 2014. Ucapan terima kasih kami sampaikan kepada Dekan FBS UNY yang telah memfasilitasi penelitian ini hingga selesai. Ucapan terima kasih juga kami sampaikan Ketua Badan Pertimbangan Penelitian FBS UNY yang telah mengoreksi dan menyemangati peneliti, Wakil Dekan I FBS UNY yang telah menyemangati peneliti, demikian juga teman sejawat dan reviewer yang telah mengoreksi dan memberi masukan artikel ini.

\section{DAFTAR PUSTAKA}

Arikunto, Suharsimi. 2013. Prosedur Penelitian: Suatu Pendekatan Praktik. Jakarta: Rineka Cipta.

Budiningsih, C. Asri. 2005. Belajar dan Pembelajaran. Jakarta: Rineka Cipta.

Depdiknas, 2010. Peraturan Pemerintah RINomor 17 Tahun 2010, tentang Pengelolaan Penyelenggaraan Pendidikan.

FIP UNY, 2013. Pendidikan untuk Pencerahan \& Kemandirian Bangsa. Yogyakarta: Ash-Shaff.

Huda Miftahul. 2011. Cooperatif Learning Methode, Teknik, Struktur dan Model Terapan. Yogyakarta: Pustaka Karya.

Lickona, T. 1999. Education for Character. New York: BANTAM.

Madya, Suwarsih. 2011. Teori dan Praktik Penelitian Tindakan. Bandung; Alfabeta.

Moleong, L. J. 2014. Metodologi Penelitian Kualitatif. Bandung; Rosdakarya.

Nurhadi. 2002. Pendekatan Kontekstual (Cotextual Teaching and Learning). Oxford: Oxford University Press. 